

\title{
Design of Maximum Power Point Tracking System Based on Single Ended Primary Inductor Converter Using Fuzzy Logic Controller
}

\author{
Muhammad Abdillah ${ }^{1}$ \\ Ronald Cornelius Batubara ${ }^{1}$ \\ Herlambang Setiadi ${ }^{2 *}$ \\ Nita Indriani Pertiwi ${ }^{1}$ \\ ${ }^{I}$ Department of Electrical Engineering, Universitas Pertamina, Jakarta, Indonesia \\ ${ }^{2}$ Faculty of Advanced Technology and Multidiscipline, Universitas Airlangga, Surabaya, Indonesia \\ * Corresponding author’s Email: h.setiadi@stmm.unair.ac.id
}

\begin{abstract}
Maximum Power Point Tracking (MPPT) is a technique developed to obtain maximum power transfer on solar panels. Various MPPT methods developed can overcome various conditions that affect the power transfer of solar panels, such as irradiation fluctuations and an increase in the solar panels surface temperature. To handle the problem fuzzy logic controller (FLC) is employed as the MPPT method. The input of FLC utilizes the error $(E)$ and delta error $(\Delta E)$ which is obtained from solar panel or photovoltaic (PV) output including voltage $V_{p v}$ and active power $P_{p v}$. Then, the output of FLC is to determine the appropriate duty cycle $(D)$ of the single-ended primary inductor converter (SEPIC) converter. This proposed scheme is to get better performance in terms of stable voltage output produced by SEPIC converter. The novelty of this paper is the combination of MPPT based on FLC or MPPT FLC that have less ripple and SEPIC that can produce stable voltage output. Hence, the ripple out the load can be reduced significantly by using this proposed method. From the simulation results, it is found that when irradiation conditions and temperatures vary, MPPT FLC can change the operating point of the solar panels close to MPP to obtain maximum power transfer. In terms of power ripple, MPPT FLC can reduce ripple (the total ripple is around $4.9 \mathrm{~W}$ ) compared to conventional MPPT such as perturb and observer $(\mathrm{P} \& \mathrm{O})$ (the total ripple is around 9.2 W). Ripple reduction occurs in both irradiation and temperature variations.
\end{abstract}

Keywords: Solar panels, MPPT, SEPIC, FLC, P\&O, Reliable electricity.

\section{Introduction}

Solar panels can be used to convert radiation from sunlight into electrical energy directly $[1,2]$. However, in reality, the amount of radiation from the sun that solar panels can receive always changes over time due to conditions [3]. In addition, an increase in the environmental temperature of the solar panel can affect the decrease in the output voltage, which causes the output power not to be generated efficiently [4]. Weather conditions are one of the main problems in installing solar panels, so the solution to this problem is to use maximum power point tracking (MPPT) in the solar power system. MPPT can ensure that the solar power system can obtain maximum power under irradiation conditions and temperature changes over time. MPPT represents the maximum power in the solar power system by changing the voltage and current at the load [5].

Solar panels can obtain maximum power by using conventional MPPT algorithms such as perturb and observe $(\mathrm{P} \& \mathrm{O})$. The $\mathrm{P} \& \mathrm{O}$ algorithm can track the maximum power point of the solar panel when the irradiation state and temperature fluctuate. The application of $\mathrm{P} \& \mathrm{O}$ algorithm for $\mathrm{PV}$ energy harvesting chip is reported in [6]. From the results it is found that $\mathrm{P} \& \mathrm{O}$ method could track a better energy of the PV. The application of $\mathrm{P} \& \mathrm{O}$ algorithm for MPPT on the partial shading condition is reported in [7]. Perturb and observe method application is also reported in [8]. However, this algorithm has the disadvantage that it has a large output power ripple 
when operating under normal conditions [9]. This is because the $\mathrm{P} \& \mathrm{O}$ algorithm uses a fixed perturbation step size, so it cannot have a fast response performance and high accuracy simultaneously [10]. If the step size is set too small, the response speed will be slow to track the MPP point when temperature and irradiation conditions change. Meanwhile, the response will have a large enough ripple at a steady state when the step size is set too large. Therefore, to overcome this limitation, it is proposed to implement a control method such as fuzzy logic controller (FLC) on MPPT.

FLC can handle complex systems such as MPPT by knowing the solar panels' power and voltage errors $(\mathrm{dP} / \mathrm{dV})$. Based on the error $(\mathrm{dP} / \mathrm{dV})$ the step size or duty cycle change (" $\Delta \mathrm{D} ")$ on the DC-DC converter will be determined periodically until the MPP is reached. The FLC method's advantage is that it does not require complicated mathematical models and is faster in responding to changing weather conditions [11]. On the other hand, conventional control methods such as PI have low efficiency and slower response than FLC because they do not adapt quickly to changes in irradiation and temperature, so that they have a larger ripple than FLC [12]. Research effort in [13], shows the efficacy of FLC for MPPT for PV system. In [13], the boost converter is used as the device for MPPT algorithm. Moreover, FLC is used as the controller of boost converter to provide a better duty cycle. From the results it is noticeable that FLC can provide high efficiency for harvesting energy from PV. However, the performance of MPPT to obtain maximum power is inseparable from the type of DC-DC converter used in the solar power system. This design uses a single-ended primary inductor converter (SEPIC) which can produce an output voltage that is greater, smaller, or equal to the input voltage. The output voltage of the SEPIC converter is controlled by the duty cycle of the control transistor, such as a mosfet. Therefore, the output voltage generated by the SEPIC converter has the same polarity as the input voltage. In addition, the SEPIC converter can reduce ripple and better efficiency than the buck-boost converter because it has two capacitors and two inductors [14]. The application of SEPIC converter for off-grid PV generation is reported in [15]. In that research to get the optimal energy harvesting from the PV, SEPIC converter controller is using $\mathrm{P} \& \mathrm{O}$ method. From the results it is noticeable that the proposed method could provide better efficiency compared to the other method.

This paper proposed an idea to reduce the ripple power in the PV power plant output by combining FLC as the MPPT and SEPIC as the DC-DC converter. In addition, by using this idea the MPPT of the PV power plant can be extracted optimally. The rest of the paper is described as follows: Section 2, described the fundamental theory of SEPIC and FLC technology as the MPPT. The design procedure of the proposed method is shown in section 3. Section 4 shows the experimental results of the proposed idea. Section 5 highlighted the contribution and conclusions of the research.

\section{Fundamental theory}

\subsection{Single ended primary inductor converter (SEPIC)}

SEPIC converter is a DC-DC converter with low output ripple with high efficiency and has the same polarity as the input voltage. Therefore, SEPIC can be used to produce an output voltage that is greater or less than the input voltage by adjusting the duty cycle. The SEPIC converter consists of several passive and active components, which can be seen in Fig. 1. The electrical components used in the SEPIC converter are two capacitors connected in series and parallel to the output, two inductors, one of which is attached to the input, one mosfet, and a diode used as a Switch mode [16]. This design uses a mosfet because it has a much higher input impedance with a lower voltage drop than a BJT. Furthermore, it does not require a bias resistor because the switching of the mosfet is controlled by a voltage difference than a current as in a BJT [17].

Switch conditions on the SEPIC can be adjusted using a pulse width modulation (PWM) signal, with a value of 0 or 1 like a digital signal. The time period in PWM is controlled by the duty cycle, which can be determined using equation one based on the input voltage and output voltage specified in the design specifications [17].

$$
D=\frac{V_{\text {out }}+V_{d}}{V_{\text {in }}+V_{\text {out }}+V_{d}}
$$

$\mathrm{V}_{\mathrm{d}}$ is the forward bias voltage of diode D1 which is usually 0.5 volts. Calculating the maximum duty cycle can use the Eq. (2).

$$
D_{\text {maks }}=\frac{V_{\text {out }}+V_{d}}{V_{\text {in }(\text { min })}+V_{\text {out }}+V_{d}}
$$

Based on Eq. (2), it can be seen the maximum duty cycle using the minimum input voltage from the design specifications. Meanwhile, to obtain the minimum duty cycle, the maximum input voltage can be used. In addition, there is a mathematical equation to determine the amount of output voltage that can be 




Figure. 1 SEPIC converter circuit

generated by the SEPIC converter based on the input voltage and duty cycle as in Eq. (3).

$$
V_{\text {out }}=\frac{D}{1-D} \times V_{\text {in }}
$$

Designing a SEPIC converter needs to decide the magnitude of the current ripple ("$\Delta \mathrm{IL} ")$ in the inductor. A good rule of thumb in designing the current ripple in an inductor is to use $20 \%$ to $40 \%$ of the maximum input current from the voltage source [18]. The ripple current flowing in the inductor $\mathrm{L}_{1}$ and $\mathrm{L}_{2}$ is the same, so it can be obtained using Eq. (4).

$$
\Delta I_{L}=I_{\text {out }} \times \frac{V_{\text {out }}}{V_{\text {in }}} \times 40 \%
$$

Then, the $\mathrm{L}_{1}$ dan $\mathrm{L}_{2}$ inductors' capacity can be obtained using Eq. (5).

$$
L=\frac{V_{i n}}{\Delta I_{L} \times f} \times D
$$

The ripple connection owned by the plugins $C_{1}$ and $C_{2}$ deserves to be different because based on [18] and [19], the ripple voltage on the capacitor at $C_{2}$ can draw $6 \%$ against maximum input voltage. While the ripple voltage on the capacitor $\mathrm{C}_{2}$ can reduce $1 \%$ of the output voltage. After obtaining the voltage ripple value, it can be seen the capacity of the athletes $C_{1}$ and $\mathrm{C}_{2}$ as in Eq. (6).

$$
C \geq \frac{I_{\text {out }} \times D}{\Delta V_{L} \times f}
$$

\subsection{MPPT FLC}

FLC has advantages in controlling systems with irregular inputs to be used in nonlinear systems [20]. FLC can be used as MPPT to obtain maximum power from solar panels because it is robust to rapid changes such as irradiation conditions and varying temperatures [21]. The working process of using FLC on MPPT can be seen in Fig. 2.

In Fig. 2, MPPT FLC uses inputs that come from $\mathrm{V}_{\mathrm{pv}}$ and $\mathrm{I}_{\mathrm{pv}}$ voltages from solar panels. After that, it is converted into error (E) by using Eq. (7) and the change in error (" $\Delta \mathrm{E} ")$ as in Eq. (8).



Figure. 2 MPPT FLC flow diagram

Table 1. Solar panels specifications SPM100-M

\begin{tabular}{|l|c|}
\hline \multicolumn{1}{|c|}{ Parameter } & Value \\
\hline Maximum Power $\left(P_{\max }\right)$ & $100 \mathrm{~W}$ \\
\hline Number of Cell & $36(6 \times 6)$ \\
\hline Maximum Voltage $\left(\mathrm{V}_{\text {mpp }}\right)$ & $18.75 \mathrm{~V}$ \\
\hline Maximum Current $\left(I_{\text {mpp }}\right)$ & $5.35 \mathrm{~A}$ \\
\hline Open-Circuit Voltage $\left(\mathrm{V}_{\mathrm{oc}}\right)$ & $22.53 \mathrm{~V}$ \\
\hline Short-Circuit Current $(\mathrm{Isc})$ & $5.7 \mathrm{~A}$ \\
\hline Temperature Coeffcients of $\mathrm{V}_{\mathrm{oc}}$ & $-0.35 \% /{ }^{\circ} \mathrm{C}$ \\
\hline Temperature Coeffcients of $I_{\mathrm{sc}}$ & $0.05 \% /{ }^{\circ} \mathrm{C}$ \\
\hline Temperature Coeffcients of $P_{\text {maks }}$ & $-0.45 \% /{ }^{\circ} \mathrm{C}$ \\
\hline
\end{tabular}

$$
\begin{aligned}
& E=\frac{P_{(n)}-P_{(n-1)}}{V_{(n)}-V_{(n-1)}} \\
& \Delta E=E_{(n)}-E_{(n-1)}
\end{aligned}
$$

\section{Design concept}

\subsection{Solar panels specifications}

In general, the specifications of solar panels are determined based on the load requirements used in the electrical system. This design using solar panel specifications, as shown in Table 1.

\subsection{SEPIC converter design}

Determining the design specifications of the SEPIC converter can be done by knowing the specifications of the solar panel as a voltage source from the SEPIC converter. Thus, the specifications of 
Table 2. SEPIC converter specifications

\begin{tabular}{|l|c|c|}
\hline \multicolumn{1}{|c|}{ Parameter } & Value & Unit \\
\hline Input Voltage $\left(V_{\text {in }}\right)$ & $10-22.53$ & $\mathrm{~V}$ \\
\hline Output Voltage $\left(V_{\text {out }}\right)$ & 18.7 & $\mathrm{~V}$ \\
\hline Output Current $\left(I_{\text {out }}\right)$ & $<5.35$ & $\mathrm{~A}$ \\
\hline Frequency & 50 & $\mathrm{kHz}$ \\
\hline
\end{tabular}

Table 3. Component capacity in SEPIC converter

\begin{tabular}{|c|c|c|}
\hline Components & Capacity & Unit \\
\hline $\mathrm{C}_{1}$ & 0.0475 & $\mathrm{mF}$ \\
\hline $\mathrm{C}_{2}$ & 0.7 & $\mathrm{mF}$ \\
\hline$L_{1}$ & 0.0431 & $\mathrm{mH}$ \\
\hline$L_{2}$ & 0.0431 & $\mathrm{mH}$ \\
\hline
\end{tabular}

the SEPIC converter are obtained, as shown in Table 2.

Based on the specifications that have been determined, the amount of capacity in each component used by the SEPIC converter circuit can be seen. The maximum input voltage in Table 2 is obtained based on the open-circuit voltage $\left(\mathrm{V}_{\mathrm{oc}}\right)$ of the solar panel using Eq. (8). The maximum duty cycle of the SEPIC converter as described in (9)

$$
D_{\max }=\frac{18.7+0.5}{12+18.7+0.5}
$$

The maximum size of the duty cycle in this design is $60 \%$. Next, perform calculations to obtain the capacity of the inductor $\mathrm{L}_{1}$ and $\mathrm{L}_{2}$. As explained in chapter 2 that both inductors have the same ripple current $\left(\Delta \mathrm{I}_{\mathrm{L}}\right)$. The ripple current in the two inductors can be determined using Eq. (4) so that the ripple current is obtained as shown in (10) and (11)

$$
\begin{aligned}
\Delta I_{L} & =5.35 \times \frac{18.7}{12} \times 40 \% \\
\Delta I_{L} & =3.33 \mathrm{~A}
\end{aligned}
$$

Based on the ripple current obtained, it can be seen the value of the capacity of the inductor $L_{1}$ and $\mathrm{L}_{2}$ as described in (12) and (13):

$$
\begin{aligned}
L & =\frac{12}{3.33 \times 50.000} \times 0,6 \\
L & =0.0431 \mathrm{mH}
\end{aligned}
$$

Capacitor $\mathrm{C}_{1}$ can be obtained using equation 2.12, assuming the ripple voltage value on the capacitor is
$6 \%$ of the input voltage based on [8] and [10] as follows:

$$
\begin{aligned}
& C_{2} \geq \frac{5.35 \times 0.6}{(1 \% \times 18.7) \times 50.000 \times 0.5} \\
& C_{2} \geq 0.7 \mathrm{mF}
\end{aligned}
$$

The load used in this design is a resistive load $(\mathrm{R})$ which can be calculated using Ohm's law as follows:

$$
\begin{aligned}
& R=\frac{18.7 V}{5.35 \mathrm{~A}} \\
& R=3.5 \mathrm{ohm}
\end{aligned}
$$

Based on [18] and [19] that the capacitor attached to the input part of the SEPIC is not very important to the performance of the SEPIC. Usually, the capacitance of capacitors connected in parallel to the input is $10 \mu \mathrm{F}$ or higher. Based on the capacity of each component obtained by using equations and mathematical calculations, the capacity of the components used in the design of the SEPIC converter can be seen in Table 3 .

\subsection{MPPT FLC design}

This design uses MPPT FLC, which uses input voltage $V_{p v}$ and current $I_{p v}$ from solar panels to obtain voltage and power error values. Based on the error value obtained, the FLC will determine the amount of increase and decrease in the duty cycle on the SEPIC to reach the $\mathrm{V}_{\mathrm{mpp}}$ voltage point. When the $\mathrm{V}_{\mathrm{pv}}$ voltage on the solar panel has approached the $\mathrm{V}_{\mathrm{mpp}}$ voltage, then MPPT FLC has succeeded in tracking the maximum power point (MPP) of the solar panel.

The block diagram of the MPPT FLC can be seen in Fig. 3. The output of the MPPT fuzzy logic controller designed is a change in the duty cycle (" $\left.\Delta \mathrm{D}^{\prime \prime}\right)$ which is used to increase or decrease the previous duty cycle (D). The value of the change in the duty cycle value in each condition depends on the error value obtained. Changes in the duty cycle will enter the PWM generator to adjust the period of changing the on and off conditions on the mosfet using digital signals, namely 0 (off) and 1 (on). The design also uses a saturation block to prevent the duty cycle value from exceeding 0.9 and less than 0.1 , because in general, the duty cycle limit is 0.1 to 0.9 . In addition, the results of this design will be compared with the results of using conventional MPPT P\&O. This aims to determine the ability of FLC in determining the MPP point and has a lower output power ripple than conventional $\mathrm{P} \& \mathrm{O}$ usage. 




Figure. 3 MPPT based on fuzzy logic controller block diagram simulation



Figure. 4 Membership function error (E)



Figure. 5 Membership function delta-error (dE)



Figure. 6 Membership function delta duty cycle $(\Delta \mathrm{D})$
Table 4. Rule Table FLC

\begin{tabular}{|c|l|l|l|l|l|}
\hline & \multicolumn{5}{|l|}{ DELTA ERROR (dE) } \\
\hline ERROR (E) & NB & NS & Z & PS & PB \\
\hline NB & NB & NB & NB & NS & Z \\
\hline NS & NB & NB & NS & Z & PS \\
\hline Z & NB & NS & Z & PS & PB \\
\hline PS & NS & Z & PS & PB & PB \\
\hline PB & Z & PS & PB & PB & PB \\
\hline
\end{tabular}

The MPPT FLC design in Fig. 3 requires fuzzy logic to determine the magnitude of the duty cycle change value based on the error value (E). The FLC design uses two inputs and one output which has a symmetrical membership function (MF). The design of the MF obtained is based on the characteristics of the system used by testing to determine the value of $E$ in the system. When the largest $E$ value is obtained, that value will be made the largest limit of the membership function (MF) in FLC. The MF form of E can be seen in Fig. 4, and the delta error $(\mathrm{dE})$ can be seen in Fig. 5, while the MF form of the delta duty cycle (" $\Delta \mathrm{D} ")$ can be seen in Fig. 6.

After designing the shape of each membership function that is used for input and output, the next step is to determine the rule. The determination of the rule is based on the system requirements of the core system, which is used as decision-making based on the inputs received by the FLC, namely E and $\mathrm{dE}$. In the MPPT FLC design, the rule table as shown in Table 4 is used to control the PWM on the MOSFET by issuing an output in the form of a change in the duty cycle. 




Figure. 7 SEPIC Circuit with MPPT FLC



Figure. 8 MPPT based on FLC for output power under various irradiation conditions

Table 5. MPPT FLC test data with varied irradiation conditions

\begin{tabular}{|c|c|c|c|}
\hline $\begin{array}{c}\text { Irradiation } \\
\left(\mathbf{W} / \mathbf{m}^{\mathbf{2}}\right)\end{array}$ & $\mathbf{V}_{\boldsymbol{p} \boldsymbol{v}}(\mathbf{V})$ & $\begin{array}{c}\text { Output } \\
\text { Power }\end{array}$ & $\begin{array}{c}\text { Duty Cycle } \\
(\%)\end{array}$ \\
\hline 1000 & 18.72 & 95.5 & 0.52 \\
\hline 900 & 18.7 & 85.6 & 0.51 \\
\hline 800 & 18.71 & 76.50 & 0.49 \\
\hline 700 & 18.69 & 69.2 & 0.48 \\
\hline 600 & 18.63 & 53.8 & 0.45 \\
\hline 500 & 18.57 & 47.9 & 0.41 \\
\hline 400 & 18.53 & 38.4 & 0.38 \\
\hline 300 & 18.33 & 28.62 & 0.36 \\
\hline 200 & 17.93 & 18.63 & 0.35 \\
\hline 100 & 17.35 & 8.6 & 0.32 \\
\hline
\end{tabular}

\section{Results and analysis}

\subsection{MPPT FLC testing}

The conditions used to determine the performance of the designed MPPT FLC are changes in temperature and irradiation. The test used varying irradiation conditions with a constant temperature of $25^{\circ} \mathrm{C}$, while the temperature variation test was carried out at constant irradiation of $1000 \mathrm{~W} / \mathrm{m}^{2}$. In addition, this test used a fixed load of $3.5 \mathrm{ohms}$ in accordance with the specified SEPIC specifications.

Changes in irradiation on solar panels will affect the output power in the design. This test uses various irradiations from $100 \mathrm{~W} / \mathrm{m}^{2}$ to $1000 \mathrm{~W} / \mathrm{m}^{2}$, so that the output power is obtained as in Fig. 8 using the conditions of each irradiation.

Based on the test results, when the irradiation conditions vary, it can be obtained each voltage,



Figure. 9 MPPT FLC output power under various temperature conditions 
power, and duty cycle in each test of the irradiation value as shown in Table 5.

In the next test, namely temperature variations, the output voltage of the solar panel will be affected, resulting in a decrease in power due to an increase in temperature. This test uses temperatures from $25{ }^{\circ} \mathrm{C}$ to $75{ }^{\circ} \mathrm{C}$ so that the output power is obtained as shown in Fig. 9.

Based on the test results, when the temperature value variation conditions are in Fig. 9, it can be obtained each voltage, power, and duty cycle for each temperature value test is shown in Table 6 .

\subsection{Comparison of results of MPPT FLC, MPPT P\&O, and without MPPT}

The capacity of each component used in this test can be seen in Table 3. This test uses a fixed load of 3.5 ohms. Comparison of output power results using irradiation conditions and varying temperatures, as well as testing the power ripple comparison between MPPT FLC, and MPPT P\&O. Fig. 10 shows the power comparison response between MPPT FLC, MPPT P\&O, and without MPPT.

Based on Fig. 10, it can be seen that the power generated by the use of MPPT can obtain a greater power transfer compared to without MPPT when the

Table 6. MPPT FLC test data with varied temperature conditions

\begin{tabular}{|c|c|c|c|}
\hline $\begin{array}{c}\text { Temperature } \\
\left({ }^{\circ} \mathrm{C}\right)\end{array}$ & $\mathbf{V}_{\boldsymbol{p} \boldsymbol{v}}$ & $\begin{array}{c}\text { Output } \\
\text { Power } \\
(\mathrm{W})\end{array}$ & $\begin{array}{c}\text { Duty } \\
\text { Cycle } \\
(\%)\end{array}$ \\
\hline 25 & $18.74 \mathrm{~V}$ & 95.5 & 0.52 \\
\hline 40 & $16.6 \mathrm{~V}$ & 84.21 & 0.53 \\
\hline 55 & $14.48 \mathrm{~V}$ & 71.75 & 0.54 \\
\hline 75 & 11.73 & 61.3 & 0.6 \\
\hline
\end{tabular}



Figure. 10 Comparison of output power between MPPT FLC, MPPT P\&O, and without MPPT under variation of irradiation conditions
Table 7. Comparison of output power between MPPT FLC, MPPT P\&O and without MPPT under irradiation variations

\begin{tabular}{|c|c|c|c|c|}
\hline Points & $\begin{array}{c}\text { Irradiation } \\
\left(\mathbf{W} / \mathbf{m}^{\mathbf{2}}\right)\end{array}$ & $\begin{array}{c}\text { MPPT } \\
\text { FLC } \\
(\mathbf{W})\end{array}$ & $\begin{array}{c}\text { MPPT } \\
\text { P\&O } \\
(\mathbf{W})\end{array}$ & $\begin{array}{c}\text { without } \\
\text { MPPT } \\
(\mathbf{W})\end{array}$ \\
\hline A & 1000 & 95.5 & 94.5 & 100.1 \\
\hline B & 800 & 76.5 & 72.5 & 71.2 \\
\hline C & 700 & 69.2 & 67.8 & 54.5 \\
\hline D & 900 & 85.6 & 78.6 & 87.4 \\
\hline E & 300 & 28.62 & 28.4 & 10.1 \\
\hline F & 500 & 47.9 & 47.8 & 27.8 \\
\hline
\end{tabular}

irradiation decreases. At points $\mathrm{A}$ and $\mathrm{D}$, namely, when the irradiation is $1000 \mathrm{~W} / \mathrm{m}^{2}$ and $900 \mathrm{~W} / \mathrm{m}^{2}$, the power produced by MPPT is lower than without MPPT. This is because the amount of resistive load used is close to the maximum power point resistance $\left(R_{\text {mpp }}\right)$ which is 3.5 ohms. Therefore, under 1000 $\mathrm{W} / \mathrm{m}^{2}$ dan $900 \mathrm{~W} / \mathrm{m}^{2}$ irradiation conditions, the resulting power transfer without MPPT is at its maximum. But in the real case, the amount of irradiation received by solar panels always varies due to weather changes. Therefore, the use of MPPT is more optimal than without MPPT. The amount of power transfer from the use of MPPT FLC, MPPT $\mathrm{P} \& \mathrm{O}$, and without MPPT based on the points specified in Fig. 10 can be seen in Table 7.

Based on Table 7, it can be seen that the power transfer obtained using MPPT FLC is greater than MPPT P\&O. When the amount of irradiation at point D is $900 \mathrm{~W} / \mathrm{m}^{2}$, MPPT FLC is able to obtain an output power of $85.6 \mathrm{~W}$. While MPPT P\&O can only produce an output power of $78.6 \mathrm{~W}$. Based on the difference in the amount of power obtained at point $\mathrm{D}$ and others, it can be concluded that MPPT FLC has better efficiency than MPPT P\&O.

The output power ripple produced by the two MPPTs can be determined by looking at the upper and lower limits of the output power. At point A, we can see the upper and lower output power limits between the two MPPTs. P\&O has an upper limit of 99.4 watts, while the lower limit is $90.2 \mathrm{~W}$. Then, it can be seen that the output power ripple using MPPT $\mathrm{P} \& \mathrm{O}$ is as follows:

$$
\begin{aligned}
& \text { ripple }_{P \& O}=99.4-90.2 \\
& \text { ripple }_{P \& O}=9.2 \mathrm{~W}
\end{aligned}
$$

It can also be seen that the upper limit of the output power using MPPT FLC is $97.3 \mathrm{~W}$, while the 
lower limit is $92.4 \mathrm{~W}$. Then it can be seen that the output power ripple using MPPT FLC is as follows:

$$
\begin{aligned}
& \text { ripple }_{F L C}=97.3-92.4 \\
& \text { ripple }_{F L C}=4.9 \mathrm{~W} \\
& \text { ripple }_{F L C}=97.3-92.4 \\
& \text { ripple }_{F L C}=4.9 \mathrm{~W}
\end{aligned}
$$

The power ripple obtained when using MPPT $\mathrm{P} \& \mathrm{O}$ is $9.2 \mathrm{~W}$, while when using MPPT FLC is 4.6 $\mathrm{W}$. Based on the ripple value obtained, it can be seen that the difference in output power ripple between MPPT FLC and P\&O is as follows:

$$
\begin{aligned}
& \text { ripple difference }=\text { ripple }_{P \& O}-\text { ripple }_{F L C} \\
& \text { ripple difference }=9.2 \mathrm{~W}-4.9 \mathrm{~W} \\
& \text { ripple difference }=4.3 \mathrm{~W}
\end{aligned}
$$

Then the difference in output power ripple between MPPT FLC and MPPT P\&O is $4.3 \mathrm{~W}$ at point A with irradiation of $1000 \mathrm{~W} / \mathrm{m}^{2}$. Based on the calculations performed at point $\mathrm{A}$, it is also known the difference in ripple at points $\mathrm{B}, \mathrm{C}, \mathrm{D}, \mathrm{E}$, and $\mathrm{F}$ using the same method. The results of observations and calculations obtained at each point can be seen in Table 8.

From Table 8 , it can be seen that at each point marked in Fig. 10, MPPT FLC has a lower output power ripple than MPPT $\mathrm{P} \& \mathrm{O}$. The difference in power ripple obtained at point $\mathrm{A}$ is $4.3 \mathrm{~W}$, at point $\mathrm{B}$ is $2.5 \mathrm{~W}$. The largest power ripple difference at point $\mathrm{C}$ is $5.8 \mathrm{~W}$. While the smallest power difference at point $\mathrm{D}$ is $0.9 \mathrm{~W}$. Finally, at point $\mathrm{E}$, the difference in The power ripple obtained is $3.3 \mathrm{~W}$. Based on this difference, it can be seen that the use of FLC in the MPPT system can reduce the output power ripple compared to conventional MPPT with an average ripple difference of $3.36 \mathrm{~W}$.

The test used temperature variations to determine the power transfer ratio between MPPT FLC, MPPT $\mathrm{P} \& \mathrm{O}$, and without MPPT, as shown in Fig. 11. In this condition, the voltage from the solar panel will decrease so that the MPP operating point will change, which causes power transfer to be not maximum. compare the output power ripple results from MPPT FLC with MPPT P\&O.

Based on Fig. 11, it can be seen that MPPT can obtain a greater power transfer than without MPPT
Table 8. Comparison of output power ripple between MPPT FLC and MPPT P\&O when conditions of irradiation variations

\begin{tabular}{|l|l|l|l|}
\hline Points & $\begin{array}{c}\text { MPPT FLC } \\
\text { Power } \\
\text { Ripple }\end{array}$ & $\begin{array}{c}\text { MPPT P\&O } \\
\text { Power } \\
\text { Ripple }\end{array}$ & $\begin{array}{c}\text { Power } \\
\text { Ripple } \\
\text { Difference }\end{array}$ \\
\hline A & $4.9 \mathrm{~W}$ & $9.2 \mathrm{~W}$ & $4.3 \mathrm{~W}$ \\
\hline B & $5.3 \mathrm{~W}$ & $7.8 \mathrm{~W}$ & $2.5 \mathrm{~W}$ \\
\hline C & $5.4 \mathrm{~W}$ & $11.2 \mathrm{~W}$ & $5.8 \mathrm{~W}$ \\
\hline D & $2.2 \mathrm{~W}$ & $3.1 \mathrm{~W}$ & $0.9 \mathrm{~W}$ \\
\hline E & $2.2 \mathrm{~W}$ & $5.5 \mathrm{~W}$ & $3.3 \mathrm{~W}$ \\
\hline Average Ripple Difference & $3.36 \mathrm{~W}$ \\
\hline
\end{tabular}



Figure. 11 Comparison of output power between MPPT FLC, MPPT P\&O and without MPPT when temperature variation conditions

Table 9. Comparison of output power between MPPT FLC, MPPT P\&O and without MPPT when temperature variation conditions

\begin{tabular}{|c|c|c|c|c|}
\hline Points & $\begin{array}{c}\text { Temperature } \\
\left({ }^{\circ} \mathbf{C}\right)\end{array}$ & $\begin{array}{c}\text { MPPT } \\
\text { FLC } \\
(\mathbf{W})\end{array}$ & $\begin{array}{c}\text { MPPT } \\
\text { P\&O } \\
(\mathbf{W})\end{array}$ & $\begin{array}{c}\text { Without } \\
\text { MPPT } \\
(\mathbf{W})\end{array}$ \\
\hline A & 25 & 95.5 & 94.5 & 100.1 \\
\hline B & 30 & 92.4 & 90.9 & 96.1 \\
\hline C & 55 & 71.75 & 66.8 & 65.9 \\
\hline D & 45 & 80.21 & 75.9 & 81.2 \\
\hline E & 75 & 61 & 56.2 & 51.2 \\
\hline
\end{tabular}

when the temperature increases at points $\mathrm{C}$ and $\mathrm{E}$. While at points $\mathrm{A}, \mathrm{B}$, and $\mathrm{D}$, the use of MPPT obtains lower power than without MPPT. This is the same as testing the condition of irradiation variations, namely because the amount of resistive load used is close to 
Table 10. Comparison of output power ripple between MPPT FLC and MPPT P\&O under temperature variation conditions

\begin{tabular}{|c|c|c|c|}
\hline Points & $\begin{array}{c}\text { MPPT } \\
\text { FLC } \\
\text { Ripple } \\
\text { Powes } \\
\text { (W) }\end{array}$ & $\begin{array}{c}\text { MPPT } \\
\text { P\&O } \\
\text { Ripple } \\
\text { Powes } \\
(\mathbf{W})\end{array}$ & $\begin{array}{c}\text { Ripple Powes } \\
\text { Difference(W) }\end{array}$ \\
\hline A & 4.9 & 9.2 & 4.3 \\
\hline B & 2.4 & 8.1 & 5.7 \\
\hline C & 4.1 & 10.8 & 6.7 \\
\hline D & 5.5 & 13.2 & 7.7 \\
\hline E & 0.8 & 11.9 & 11.1 \\
\hline Average Ripple Difference & 7.1 \\
\hline
\end{tabular}

the maximum power point resistance $\left(\mathrm{R}_{\mathrm{mpp}}\right)$ of 3.5 ohms. However, in the real case, the surface temperature of the solar panel will increase when operating under optimal conditions, namely during the day. Therefore, the use of MPPT is more optimal than without MPPT because, at point E or the hottest temperature of the test, MPPT managed to obtain a greater power transfer than without MPPT. The amount of power transfer from the use of MPPT FLC, MPPT P\&O, and without MPPT based on the points specified in Fig. 11 can be seen in Table 9.

From Table 9, it can be seen that when there is an increase in temperature above $45^{\circ} \mathrm{C}$, MPPT FLC can obtain a greater power transfer than without MPPT. The difference in the amount of power produced due to MPPT FLC can change the operating point of the voltage from the solar panel to produce maximum power transfer. If MPPT FLC is compared with MPPT $\mathrm{P} \& \mathrm{O}$, it is known that MPPT FLC has a higher power transfer when the temperature changes conditions. Therefore, the efficiency of MPPT FLC is higher than MPPT P\&O when the temperature varies. Based on the results obtained when irradiation conditions and temperatures vary, it can be seen that the use of FLC in the MPPT system will be beneficial to obtain maximum power transfer from solar panels.

As in the irradiation variation test, temperature changes result in a change in the operating point of the voltage from the solar panel so that the power transfer obtained will be different in each condition. It can be seen in Fig. 11 that the difference in output power ripple between the two MPPT algorithms can be seen directly. The large difference in ripple values obtained from MPPT FLC and P\&O can be obtained by observing the upper and lower limits of the graph in Fig. 11. Ripple data under conditions of temperature variation are as shown in Table 10.

In Table 10, it can be seen that at each point marked in Fig. 11, MPPT FLC has a lower output power ripple than MPPT $\mathrm{P} \& \mathrm{O}$. The difference in ripple power obtained at point $\mathrm{B}$ is $5.7 \mathrm{~W}$, at point $\mathrm{C}$ is $6.7 \mathrm{~W}$, at point $\mathrm{D}$ is $7.7 \mathrm{~W}$, and at point $\mathrm{E}$ is 11.1 $\mathrm{W}$. Based on the data obtained, the higher the ambient temperature of the solar panel, the larger the power ripple from the use of MPPT P\&O. Therefore, MPPT FLC can be said to be superior to MPPT FLC when compared to MPPT P\&O with an average power ripple difference of $7.1 \mathrm{~W}$ under conditions of temperature variation.

\section{Conclusion}

The MPPT FLC design succeeded in changing the operating point of the solar panel voltage to the Vmpp point to obtain maximum power transfer. Under STC conditions, MPPT FLC succeeded in changing the operating voltage of the solar panel to 18.73 volts with a maximum power of 95.5 watts. When irradiation conditions and temperatures vary, MPPT FLC can keep up with changing conditions by obtaining maximum power from each change. MPPT FLC can reduce power ripple at lower loads than MPPT P\&O. The difference in power ripple using MPPT FLC when the STC condition is 4.3 Watt. When the irradiation conditions and temperature vary, the average ripple power difference is $3.36 \mathrm{~W}$ and 7.1 $\mathrm{W}$ between MPPT FLC and MPPT P\&O.

\section{Conflicts of interest}

The authors declare no conflict interest.

\section{Author contributions}

Conceptualization, Muhammad Abdillah and Ronald Cornelius Batubara; methodology, Muhammad Abdillah and Nita Indriani Pertiwi; software, Ronald Cornelius Batubara and Muhammad Abdillah; validation, Muhammad Abdillah and Nita Indriani Pertiwi; formal analysis, Nita Indriani Pertiwi and Herlambang Setiadi; investigation, Muhammad Abdillah and Herlambang Setiadi; resources, Muhammad Abdillah; data curation, Muhammad Abdillah and Ronald Cornelius Batubara; writing - original draft preparation, Herlambang Setiadi and Ronald Cornelius; writingreview and editing, Herlambang Setiadi and Nita Indriani P; visualization, Muhammad Abdillah, Nita Indriani Pertiwi and Herlambang Setiadi. All authors 
have read and agreed to the published version of the manuscript.

\section{References}

[1] H. Setiadi and M. Abdillah, "Simultaneous Parameter Tuning of PSS and Wide-Area POD in PV Plant using FPA", Engineering Journal, Vol. 23, No. 6, pp. 55-66, 2019.

[2] H. Setiadi, N. Mithulananthan, and R. Shah, "Design of wide-area POD with resiliency using modified DEA for power systems with high penetration of renewable energy", IET Renewable Power Generation, Vol. 13, No. 2, pp. 342-351, 2018.

[3] H. Setiadi, N. Mithulananthan, R. Shah, K. Y. Lee, and A. U. Krismanto, "Resilient wide-area multi-mode controller design based on Bat algorithm for power systems with renewable power generation and battery energy storage systems", IET Generation, Transmission \& Distribution, Vol. 13, No. 10, pp. 1884-1894, 2019.

[4] H. Setiadi, N. Mithulananthan, R. Shah, T. Raghunathan, and T. Jayabarathi, "Enabling resilient wide-area POD at BESS in Java, Indonesia $500 \mathrm{kV}$ power grid", IET Generation, Transmission \& Distribution, Vol. 13, No. 16, pp. 3734-3744, 2019.

[5] A. F. Mirza, M. Mansoor, K. Zhan, and Q. Ling, "High-efficiency swarm intelligent maximum power point tracking control techniques for varying temperature and irradiance", Energy, Vol. 228, p. 120602, 2021.

[6] J. Z. Yan, W. H. Pan, H. H. Wu, T. Hsu, and C. L. Wei, "Photovoltaic Energy Harvesting Chip with $\mathrm{P} \& \mathrm{O}$ Maximum Power Point Tracking Circuit and Novel Pulse-Based Multiplier", IEEE Transactions on Power Electronics, 2021.

[7] L. Bhukya, A. Annamraju, and S. Nandiraju, "A novel maximum power point tracking technique based on Rao-1 algorithm for solar PV system under partial shading conditions", International Transactions on Electrical Energy Systems, p. e13028, 2021.

[8] S. Lyden, H. Galligan, and M. E. Haque, "A hybrid simulated annealing and perturb and observe maximum power point tracking method", IEEE Systems Journal, 2020.

[9] A. F. Mirza, M. Mansoor, K. Zhan, and Q. Ling, "High-efficiency swarm intelligent maximum power point tracking control techniques for varying temperature and irradiance", Energy, Vol. 228, p. 120602, 2021.
[10] S. Mohanty, B. Subudhi, and P. K. Ray, "A New MPPT Design Using Grey Wolf Optimization Technique for Photovoltaic System Under Partial Shading Conditions", IEEE Transactions on Sustainable Energy, Vol. 7, No. 1, pp. 181188, 2016, doi: 10.1109/TSTE.2015.2482120.

[11] A. Rajavel and N. R. Prabha, "Fuzzy logic controller-based boost and buck-boost converter for maximum power point tracking in solar system", Transactions of the Institute of Measurement and Control, Vol. 43, No. 4, pp. 945-957, 2021.

[12] M. N. Ali, K. Mahmoud, M. Lehtonen, and M. M. F. Darwish, "Promising MPPT Methods Combining Metaheuristic, Fuzzy-Logic and ANN Techniques for Grid-Connected Photovoltaic", Sensors, Vol. 21, No. 4, p. 1244, 2021.

[13] K. Nebti and R. Lebied, "Fuzzy maximum power point tracking compared to sliding mode technique for photovoltaic systems based on DC-DC boost converter", Electrical Engineering \& Electromechanics, Vol. 1, pp. 67-73, 2021.

[14] V. Kumar, S. Ghosh, N. K. S. Naidu, S. Kamal, R. K. Saket, and S. K. Nagar, "A current sensor based adaptive step-size MPPT with SEPIC converter for photovoltaic systems", IET Renewable Power Generation, Vol. 15, No. 5, pp. 1085-1099, 2021.

[15] S. Kaliappan, et al., "Off-Grid Power Generation using SEPIC Converter with $\mathrm{P} \& \mathrm{O}$ for PV System", Annals of the Romanian Society for Cell Biology, pp. 3907-3913, 2021.

[16] J. D. D. N. Ndongmo, G. Kenné, R. K. Fochie, A. F. T. Njomo, and E. M. Nfah, "Adaptive neuro-synergetic control technique for SEPIC converter in PV systems", International Journal of Dynamics and Control, pp. 1-14, 2021.

[17] B. R. Kumar, D. Naveen, V. S. Kumar, and L. Vignesh, "PSO BASED MPPT TECHNIQUE FOR MODIFIED SEPIC CONVERTER IN PV SYSTEM USING IOT", Turkish Journal of Physiotherapy and Rehabilitation, Vol. 32, p. 2.

[18] D. Sivamani, R. Ramkumar, A. N. Ali, and D. Shyam, "Design and implementation of highly efficient UPS charging system with single stage power factor correction using SEPIC converter", Materials Today: Proceedings, Vol. 45, pp. 1809-1819, 2021.

[19] K. S. Kavin and P. S. Karuvelam, "PV-based Grid Interactive PMBLDC Electric Vehicle with High Gain Interleaved DC-DC SEPIC Converter", IETE Journal of Research, pp. 1-15, 2021. 
[20] T. Kerdphol, M. Watanabe, K. Hongesombut, and Y. Mitani, "Self-adaptive virtual inertia control-based fuzzy logic to improve frequency stability of microgrid with high renewable penetration", IEEE Access, Vol. 7, pp. 7607176083, 2019.

[21] M. N. Ali, K. Mahmoud, M. Lehtonen, and M. M. F. Darwish, "Promising MPPT Methods Combining Metaheuristic, Fuzzy-Logic and ANN Techniques for Grid-Connected Photovoltaic", Sensors, Vol. 21, No. 4, p. 1244, 2021. 